\title{
Obituaries
}

\section{Jacques Benveniste}

Immunologist who caused controversy by claiming to have proved the principle of homoeopathy

No one familiar with the career of Dr Jacques Benveniste will be at a loss to understand why the company founded to support his research should have marked his death with a press release quoting the great French physiologist Claude Bernard: "When the fact that we come up against does not agree with the predominant theory that we have accepted, we must take the fact and abandon the theory." The facts that Benveniste claimed to have uncovered altered the course of his life. Whether his change of direction was justified-indeed whether the facts really were as he believed them to be-generated a debate that intrigued biomedical scientists for several months during the late $1980 \mathrm{~s}$.

At that time Benveniste was head of allergy and inflammation immunology at the French biomedical research agency INSERM (Institut de la Santé et de la Recherche Médicale). The saga began when a member of his staff put a homoeopathically diluted remedy through an allergy test devised by Benveniste, and obtained a positive result. Greatly puzzled, Benveniste and his collaborators began experimenting.

Their results, published in Nature in 1988, created an uproar (Nature 1988;333:816-8). The test itself uses polymorphonuclear basophils. When IgE antibodies on their surfaces are exposed to antiIgE antibodies they degranulate, releasing histamine. The INSERM researchers claimed to show that the effect could be detected with anti-IgE diluted to $1 \times 10^{120}$. At a dilution of just $1 \times 10^{14}$ any one assay might be expected to contain no more than a single molecule of IgE. Yet Benveniste was detecting degranulation when, by common consent, most assays would have none at all.

Significantly, the effect was only apparent if the successive dilutions were accompanied by vigorous agitation. This, the authors suggested, had induced "a sub-molecular organization of water": a memory, as it was generally described.

Nature had deep doubts about this apparent proof of the principle of homoeopathy, and expressed them in an "Editorial reservation" printed at the end of the paper: "Readers of this article may share the incredulity of the many referees who

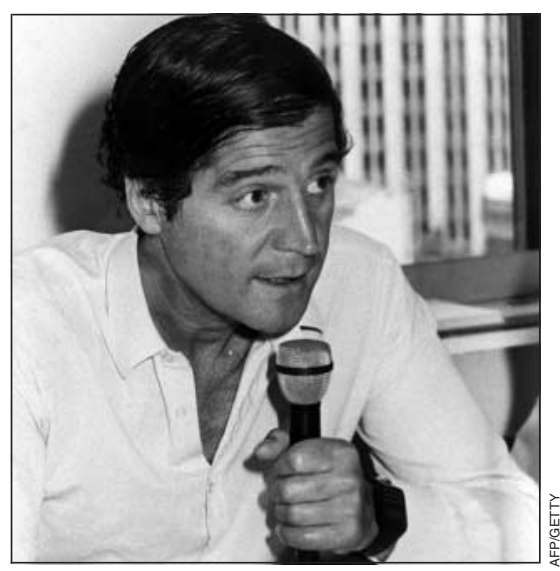

have read it ... With the kind collaboration of Professor Benveniste, Nature has therefore arranged for independent investigators to observe repetitions of the experiments."

Whether this unusual approach demonstrated admirable fairness by Nature's staff, or a discreditable attempt to have their cake and eat it, Benveniste himself was deeply upset by the conduct of the investigation. Famously, the team comprised Nature's then editor, John Maddox, and two Americans: Walter Stewart, a scientist skilled at exposing scientific fraud, and the magician James Randi.

Their report-one of the most unusual ever published in that journal-pulled no punches (Nature 1988; 334:287-90). Its opening paragraph described Benveniste's experiments as "statistically ill-controlled, from which no effort has been made to exclude systematic error, including observer bias, and whose interpretation has been clouded by the exclusion of measurements in conflict with the claim that anti-IgE at 'high dilution' will degranulate basophils. The phenomenon described is not reproducible..."

The four pages of revelation and criticism were spiced with accounts of sloppy lab procedure, enriched with details of the team's fraud-busting techniques (videorecording of procedures; taping sealed experimental codes to the laboratory ceiling), and iced with dollops of pure journalism.

Maddox offered not to publish their conclusions if Benveniste withdrew the paper.
Benveniste did not; Maddox published. In a bitterly angry riposte Benveniste described the investigation as a mockery of scientific inquiry, and compared it to a Salem witch hunt or a McCarthyite prosecution.

Benveniste earned a reprimand from INSERM but survived a 1990 evaluation of his lab's work on condition that he stop experimenting with high dilutions. The lab failed a subsequent assessment in 1994, and was closed.

Undaunted, Benveniste went on to develop what he called "digital biology": the science and technology of the molecular information stored by water (its "memory"). This information, he claimed, could be transmitted from one molecule to another by electromagnetic signals. 1997 saw the advent of DigiBio, a company created to develop and exploit digital biology commercially.

Hailed by some homoeopaths as the messiah bringing scientific respectability, Benveniste continued to have many loyal supporters. The scientific community in general dismissed him as honest but self-deluding. He became the first person to win two of the Ig Nobel prizes awarded annually by the Harvard-based journal Annals of Improbable Research. One was for the alleged memory of water, the other for his claim to be able to transmit such memories via the internet.

All this hoopla eclipsed the earlier and less troubled phase of Benveniste's career. Trained in Paris he qualified in 1960 and practised medicine in that city before taking a research job in cancer. After three years at the Scripps Clinic in California he returned to France and joined INSERM in 1980 as head of its allergy unit. He became a senior research director in 1984, and emeritus research director in 2002. His reputation as an orthodox researcher derives from his 1970 discovery of platelet activating factor (PAF).

Water may have no memory, but science does. L'affaire Benveniste, and its eponymous progenitor, will not be forgotten. [GEOFF WaTts]

Jacques Benveniste, French immunologist (b Paris 1935; q Paris 1960), died in Paris on 3 October 2004 following heart surgery. 


\section{Matthew Macmaster Garrey}

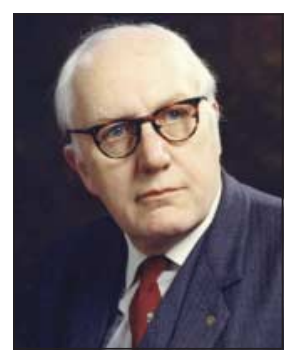

Former obstetrician and gynaecologist Glasgow (b Ayr 1914; q Glasgow 1936; DPH, FRCOG, FRCS Glas), d 4 October 2004.

Matthew was an expert in difficult vaginal delivery before caesarean section became as popular and safe as it is today. He was interested in boats and was a founder member of the Clyde River Steamer Club. After retirement he was for 10 years a guide at the famous Burrell Collection, where his particular interest was the stained glass. He leaves a wife, Margery; four children; and nine grandchildren. [Malcolm Macnaughton]

\section{Philip Glazer}

Former consultant anaesthetist Radcliffe Infirmary, Oxford (b 1913; q King's College London 1935; DA, FFA RCS), died from pneumonia on 11 November 2003.

At the outbreak of the second world war Philip joined the Royal Army Medical Corps and served in Iraq, Egypt, and India, where he worked as an anaesthetist. He left in 1945 with the rank of major. In 1948 he was appointed consultant anaesthetist at the Horton Hospital, Banbury. Two years later he joined the Nuffield Department of Anaesthetics in Oxford. He retired from this post in 1978 but worked for several more years with the Oxford Blood Transfusion Service. Philip was an expert woodworker and furnished his and his daughters' houses. Predeceased by his wife, Elizabeth, he leaves two daughters and five grandchildren. [Amanda Glazer, Susan Glazer, John Henville]

\section{Margaret Marian Horne (née Robertson)}

Former general practitioner Tain, Ross and Cromarty (b Cullen 1913; q Aberdeen 1937; MRCGP), died following a femoral fracture on 20 July 2004

While working as a medical officer at Invergordon Hospital Marian met and married Dr Colin Mackenzie, subsequently joining him in practice in Alness. When her husband served in the second world war, she ran the practice singlehandedly, also serving as medical officer to the naval base at Invergordon. Following the war, the family moved to a practice in Tain, where she again worked singlehandedly following the death of her husband in 1949. In 1953 she remarried. She continued in practice, eventually with two partners till her retirement in 1974. Predeceased by her second husband, she leaves two daughters and five granddaughters. [ANDREW G C ROBERTSON]

\section{Margaret Jean Parbrook}

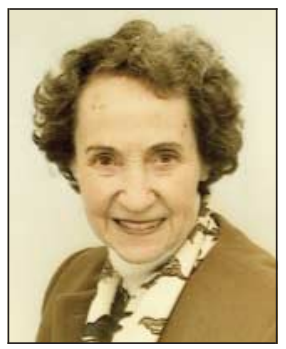

Former consultant anaesthetist North Manchester Hospitals (b County Durham 1923; $q$ Durham 1947), died from carcinomatosis on 25 September 2004.

Margaret did her house jobs at the Queen Elizabeth and General hospitals in Birmingham. Her early anaesthetic posts were also in the Birmingham area. She spent seven years as a locum consultant at Selly Oak Hospital before moving to the North Manchester Hospitals, where she was appointed consultant in 1963. She was later appointed an honorary associate lecturer to Manchester University. She played an active role in the teaching of junior staff and was elected vice chairman of the anaesthetic division. Margaret retired in 1985. She never married. [G Parbrook, D Morrison]

\section{Bruce Thomas}

Former general practitioner Waterlooville, Hampshire, and lecturer in primary medical care University of Southampton (b 1916; $q$ Liverpool 1943; MD), died from urinary tract septicaemia on 9 June 2004.

Bruce Thomas served in the Royal Army Medical Corps in India for three years during the second world war, before completing house jobs. He entered singlehanded general practice in Waterlooville in 1957. He developed an interest in psychological medicine and wrote his MD thesis on the temporarily dependent patient. He also published a series of articles about the consultation in the BMJ. Following his retirement from full time practice he became a member of the clinical academic staff at the University of Southampton. He leaves a wife, Glenys, and four children. [ANN Louise KinMonth, John BAIN]

\section{David William Phillip Thomas}

Former general practitioner Cardiff (b London 1930; q Cambridge/St Bartholomew's Hospital, London, 1956), died from motor neurone disease on 26 December 2003.
David did his national service in the Royal Artillery before going up to Cambridge. After house jobs and various locum jobs he travelled widely, as well as working in Africa and as a ship's surgeon in the merchant navy. He joined the practice in Cardiff where he had been one of the first trainees, staying there until he retired. For many years he was a clinical assistant at the University Hospital of Wales and a medical officer to the Civil Service Advisory Service. He leaves a wife, Margaret, and two children. [MARGARET Thomas]

\section{Peter Holmes Watkins}

General practitioner Herne Bay, Kent 1960-89 (b King's Lynn 1926; q St Bartholomew's Hospital,London, 1950), d 17 August 2004. After national service in Egypt Peter worked at Harefield Hospital for three years. In 1960 he moved to Herne Bay, where he joined a two handed practice serving a mixed town and rural practice, and also a mining village. Over the years he helped the practice grow to five partners and become a training practice. He also served as medical officer to the local hospital for the elderly, and lectured and examined for the Red Cross for many years. He leaves a wife, Mary; two children; and six grandchildren. [ERIC WATKINS]

\section{John Donald ("Paddy") Whiteside}

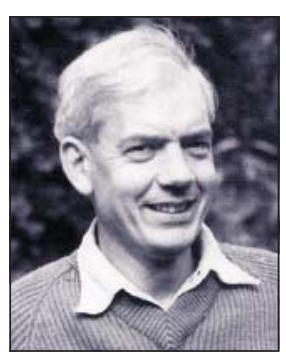

Consultant general physician and cardiologist St Richard's Hospital, Chichester, 1946-77 and King Edward VII Hospital, Midhurst (b Dublin 1916; q Trinity College Dublin 1939; MD, MRCPI, FRCP), d 30 June 2004.

After house posts in England Paddy enlisted with the Royal Air Force and, with his field hospital, went to the Low Countries, where he met his future wife. At St Richard's he created a coronary care unit and diagnostic cardiac service. For 25 years Paddy also devoted his energies to the building, management, and development of the Aldingbourne Centre (for those with learning disabilities), of which he was the founder chairman. He leaves a wife, Els; three children; and five grandchildren. [M W N Nicholls]

Longer versions of these obituaries are available on bmj.com 